Original Contribution

\title{
MORPHOLOGICAL AND PHENOTYPIC CHARACTERISTICS OF DONKEYS IN SOME REGIONS OF BULGARIA
}

\author{
R. Vlaeva*, S. Georgieva, G. Barzev, I. Ivanova \\ Department of Non-ruminant and Other animals, Faculty of Agriculture, Trakia University, \\ Stara Zagora, Bulgaria
}

\begin{abstract}
The aim of the recent study was to determine the morphological characteristics of the donkey population in some areas of Bulgaria. The number of donkeys included in the research was 96, bred in three regions of Bulgaria - Kardzhali, Stara Zagora and Sofia. Four exterior measurements were taken from each donkey as follow: height at withers, body length, chest circumference and cannon bone circumference. Height at withers and body length were measured with measuring stick the two circumferences were taken with measuring tape. The main coat color of the donkeys was determent as part of the study. The estimated mean value for height at withers was $119.8 \mathrm{~cm}$ with variation within the range of $99 \mathrm{~cm}$ to $148 \mathrm{~cm}$; the mean body length value was $124 \mathrm{~cm}$ ranging from $102 \mathrm{~cm}$ to $154 \mathrm{~cm}$. Chest circumference ranged from $115 \mathrm{~cm}$ to $160 \mathrm{~cm}$, average $136 \mathrm{~cm}$ and cannon bone circumference is with mean value of $16 \mathrm{~cm}$ varying from $13 \mathrm{~cm}$ to $20 \mathrm{~cm}$. More common coat colors of the examined donkeys were brown and grey with the typical dark cross on the back.
\end{abstract}

Key words: donkey, body measurements, coat color,

\section{INTRODICTION}

The coexistence of man and donkey dates back to ancient times. Known for their durability and unpretentiousness to the conditions in which they are raised the donkey population in Bulgaria reaches its largest number during the second half of the 20th century. Nowadays their population is highly reduced and this trend spread all over Europe. This defines the donkeys as a suitable subject of many scientific studies and projects for their preservation. The most common topics of discussion are the morphological and phenotypic characteristics of donkeys. In regard of this the body condition, live weight and body dimensions of 516 working donkeys in Morocco are examined (1). In Cameroon the effect of "dry season" on live weight and some body measurements of donkeys used for work are studied (2). The study includes a total number of 135 donkeys between 2 and 15 years of age. Height at withers varies from 90 to $110 \mathrm{~cm}$ and body length range widely from 115 to $173 \mathrm{~cm}$. Other authors investigate the body development of two donkey breeds (Poitevian and Catalan) and their crosses. The

\footnotetext{
*Correspondence to: Radka Vlaeva, Department of Non-ruminant and other animals, Faculty of Agriculture, Trakia University, 6000 Stara Zagora, Bulgaria, email: rvlaeva@gmail.com
}

results show little difference in body measurements among individuals of the two breeds (3). In Banat great variety of body measures, colors and hues is reported on 94 donkeys (4). In Turkey the morphological characteristics of 94 donkeys (56 male and 38 female) are examined (5). The authors also examine the morphological characteristics of donkeys in Eastern and Southeastern Turkey and compare them with other breeds of donkeys worldwide (6). The results of their studies show that donkeys grown in Turkey have relatively low values for height at withers - from $98.6 \mathrm{~cm}$ to $102.3 \mathrm{~cm}$. In Czech Republic is reported a relatively low value for height at withers $-104 \mathrm{~cm}$, as the authors study the factors influencing body dimensions and some hipometric indices of 15 jacks and 35 jennets (7).

Having in mind the wide variation in morphological characteristics found in donkeys by many authors, the aim of this study was to determine the morphological characteristics of the donkey population in some areas of Bulgaria.

\section{MATERIAL AND METHODS}

The study includes total number of 96 donkeys reared in the regions of Kardzali, Stara Zagora and Sofia. Four exterior measurements were 
collected from each donkey as follow: height at withers, body length, chest circumference and cannon bone circumference. The main coat color was determent using the routine zootechnical methods. The exterior measurements data was analyzed using the STATISTICA software, version 6.1 (8) for the whole studied population and divided by regions.

\section{RESULTS AND DISCUSSION}

The results of statistical processing for the examined four body measurements are presented in Table 1. Height at withers is with estimated mean value of $119.8 \mathrm{~cm}$ with variation within the range of $99 \mathrm{~cm}$ to $148 \mathrm{~cm}$, the mean body length value is $124 \mathrm{~cm}$ ranging from $102 \mathrm{~cm}$ to $154 \mathrm{~cm}$. Chest circumference range from $115 \mathrm{~cm}$ to $160 \mathrm{~cm}$, average $136 \mathrm{~cm}$ and cannon bone circumference is with mean value of $16 \mathrm{~cm}$ varying from $13 \mathrm{~cm}$ to $20 \mathrm{~cm}$. When compared by regions the greatest height at withers were measured on donkeys raised in Stara Zagora region - $126.09 \mathrm{~cm}$, while the lowest value is taken of the donkeys in Sofia region. The highest value for body length $133.09 \mathrm{~cm}$ was estimated also on donkeys from Stara Zagora district, followed by donkeys from Kardzhali district $-125.16 \mathrm{~cm}$. Regarding the chest circumference and cannon bone circumference again the highest values are obtained from donkeys in Stara Zagora region, $143.18 \mathrm{~cm}$ and $17.04 \mathrm{~cm}$ respectively, followed by donkeys in the region of Kardzhali.

Based on the assessment of the exterior measurement of the donkeys included in the study we can conclude that the donkeys raised in the plane areas of the country have greater height at withers and elongated body compared to the donkeys bred in the mountain areas. The examined individuals in the plane areas show significant varying in minimal and maximal values of height at withers $-20 \mathrm{~cm}$, and body length $-29 \mathrm{~cm}$. Similar trend is observed and for the other two measurements.

The greatest value for height at withers (148 $\mathrm{cm})$ was measured on donkey in the Kardzali region, where we came across of just one jennet, all others were mainly geldings, which means that in this area there is no breeding process and the animals are brought there from other regions of the country.

Table 1. Estimated values of the studied exterior measurements in donkeys distributed by regions.

\begin{tabular}{|c|c|c|c|c|}
\hline & $\mathbf{n}$ & Mean \pm Std. Dev & Min. & Max. \\
\hline height at withers (h) in cM. & & & & \\
\hline Kardzhali region & 67 & $120,61 \pm 7,35$ & 105,0 & 148,0 \\
\hline Stara Zagora region & 11 & $126,09 \pm 6,73$ & 119,0 & 139,0 \\
\hline Sofia region & 18 & $112,94 \pm 7,21$ & 99,0 & 123,0 \\
\hline TOTAL & $\mathbf{9 6}$ & $\mathbf{1 1 9 , 8 0} \pm \mathbf{8 , 0 9}$ & $\mathbf{9 9 , 0}$ & $\mathbf{1 4 8 , 0}$ \\
\hline Kardzhali region & & & & \\
\hline Stara Zagora region & 67 & $125,16 \pm 7,73$ & 105,0 & 149,0 \\
\hline Sofia region & 11 & $133,09 \pm 9,55$ & 125,0 & 154,0 \\
\hline TOTAL & 18 & $117,06 \pm 8,83$ & 102,0 & 136,0 \\
\hline Kardzhali region & $\mathbf{9 6}$ & $\mathbf{1 2 4 , 6 4} \pm \mathbf{9 , 2 8}$ & $\mathbf{1 0 2 , 0}$ & $\mathbf{1 5 4 , 0}$ \\
\hline Stara Zagora region & & & & \\
\hline Sofia region & 66 & $138,31 \pm 8,84$ & 116,0 & 160,0 \\
\hline TOTAL & 11 & $143,18 \pm 8,85$ & 128,0 & 158,0 \\
\hline Kardzhali region & 18 & $126,78 \pm 7,81$ & 115,0 & 139,0 \\
\hline Stara Zagora region & $\mathbf{9 5}$ & $\mathbf{1 3 6 , 6 9 \pm 9 , 9 4}$ & $\mathbf{1 1 5 , 0}$ & $\mathbf{1 6 0 , 0}$ \\
\hline Sofia region & & & & \\
\hline TOTAL & 67 & $16,18 \pm 0,14$ & 13,0 & 20,0 \\
\hline & 11 & $17,04 \pm 1,23$ & 15,0 & 19,0 \\
\hline & 18 & $14,75 \pm 1,09$ & 13,0 & 17,0 \\
\hline $\mathbf{9 6}$ & $\mathbf{1 6 , 0 1} \pm \mathbf{1 , 3 5}$ & $\mathbf{1 3 , 0}$ & $\mathbf{2 0 , 0}$ \\
\hline
\end{tabular}

The morphological characteristics of the donkeys are subject to many other studies. In Table 2 are presented the results of some authors compared with the results from recent research. The comparative analysis shows that with highest mean value for height at withers $(139,5 \mathrm{~cm})$ are donkeys in Morocco followed by $119,8 \mathrm{~cm}$ measured on donkeys in the recent study. For the other three exterior measurements (body length, chest circumference and cannon bone circumference) again the greatest mean values are reported for the donkeys in Marocco.

For the donkey population examined in the recent study mean values for chest circumference and cannon bone circumference take second place with values of $136,69 \mathrm{~cm}$ 
VLAEVA R., et al.

and $16,01 \mathrm{~cm}$ respectively. Regarding the body length the greatest values are observed on donkeys in Marocco - 139,8 cm and Cameroon $-137,3 \mathrm{~cm}$ the studied population in Bulgaria comes on third place with mean of $124,6 \mathrm{~cm}$.
Results reported for donkey population in Turkey show that despite the close geographical location donkeys in Bulgaria differ significantly from those in Turkey in height and massiveness.

Table 2. Comparative analysis of the exterior measurements with the results of other authors.

\begin{tabular}{|l|c|c|c|c|}
\hline \multicolumn{1}{|c|}{ exterior trait } & $\begin{array}{c}\text { height at } \\
\text { withers }(\mathbf{c m})\end{array}$ & $\begin{array}{c}\text { body length } \\
\mathbf{( c m )}\end{array}$ & $\begin{array}{c}\text { chest } \\
\text { circumference } \\
(\mathbf{c m})\end{array}$ & $\begin{array}{c}\text { cannon bone } \\
\text { circumference } \\
(\mathbf{c m})\end{array}$ \\
\hline recent study & $\mathbf{1 1 9 , 8 0}$ & $\mathbf{1 2 4 , 6 4}$ & $\mathbf{1 3 6 , 6 9}$ & $\mathbf{1 6 , 0 1}$ \\
\hline Ebangi \& Vall (2005) & 98,05 & 137,26 & 107,53 & - - - \\
\hline Boujenane \& Machmoum (2008) & 139,50 & 139,80 & 151,00 & 19,60 \\
\hline Yilmaz \& Ertuğrul (2011) & 99,10 & 103,00 & 111,50 & 13,40 \\
\hline Matiuti et al. (2011) & 105,00 & 121,00 & - - & - - - \\
\hline
\end{tabular}

The coat color of the examined donkeys varies, as more common were brown and grey with the typical dark cross on the back. Those two colors also occur in the lighter and darker shades. Black and roan coat colors were observed on few individuals.

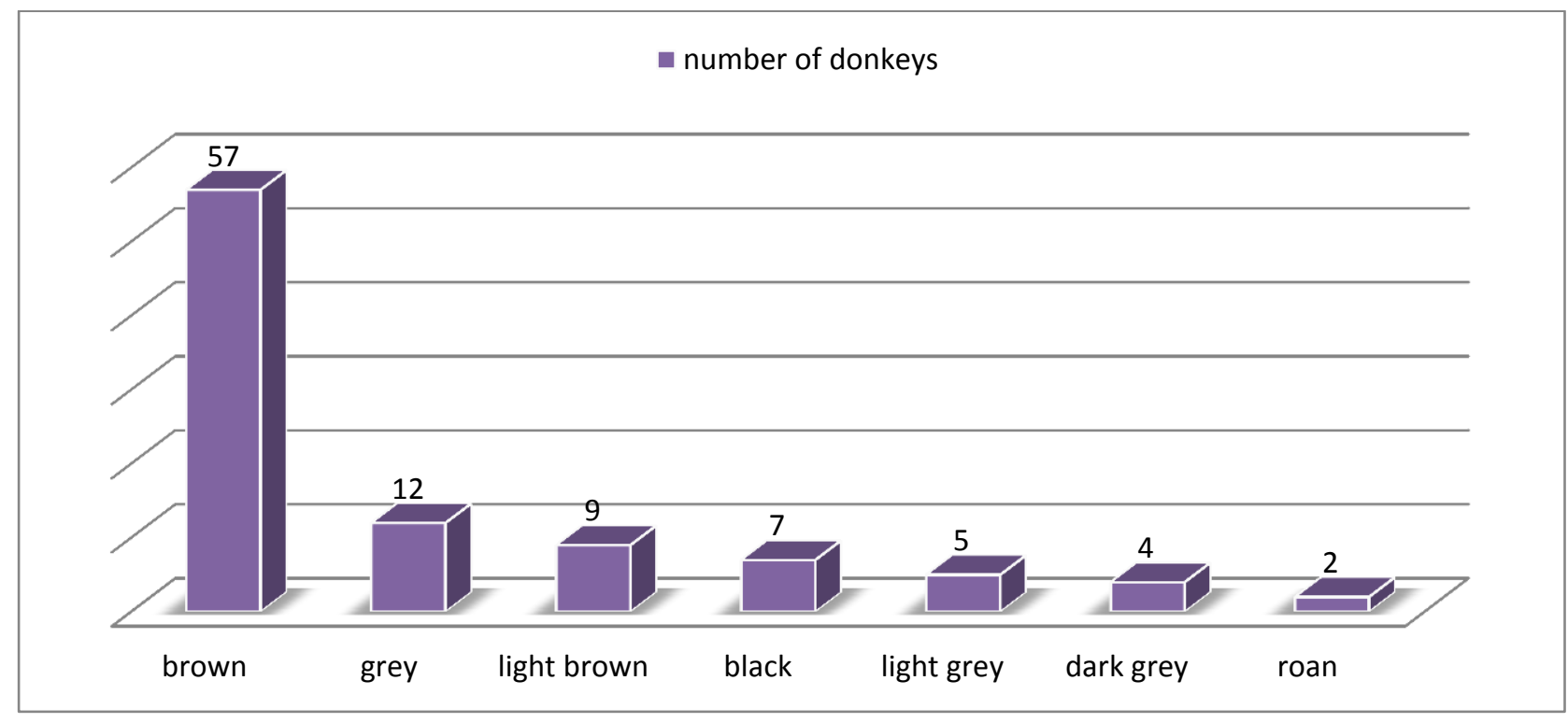

Figure 1. Number of donkeys divided by coat color

\section{CONCLUSION}

The donkeys raised in the plane areas of the country have greater height at withers and elongated body compared to the donkeys bred in the mountain areas. Greatest mean values for all of the examined exterior measurements are observed in donkeys raised in the region of Stara Zagora. Comparatively high values of the body measurements obtained from donkeys bred in Kardzali area are due to the fact that most or the animals in the area are bought from other regions of the country. Most common coat color is brown identified on 57 donkeys followed by gray and light grey coat color.

\section{ACKNOWLEDGMENT}

This work was supported financially by Project 7Ж/14, Trakia University, Faculty of Agriculture.

The authors would like to thank to the mayor of municipality of Dzhebel and the mayors of the villages Pripek, General Geshevo, Padina, Sedlartsi and Zhaltusha for their kind cooperation, as well to the national veterinary service offices in Dzhebel and Ardino. 


\section{REFERENCES}

1. Pearson A., Ouassat, M., Estimation of the liveweight and body condition of working donkeys in Morocco. Veterinary Record 138, 229-233, 1996.

2. Ebangi A. L., Vall, E., Dry season effect on live weight and some body dimentions of working donkeys in the Sudano-sahel region of Cameroon. Tropicultura 23 (1), 48-53, 2005.

3. Boujenane I., Machmoum, M., Mensurations corporelles des ânes des races Poitevine et Catalane et de leurs croisés au Maroc. Revue Élev. Méd. Vét. Pays trop. 61 (1), 63-67, 2008.

4. Matiuti M., Matiuti, C., Dronca, D., Nistor, E., Mo,t T., Research on Donkey Population (Equus Asinus) in Banat. Animal Science and Biotehnologies, 44 (1), 2011.
5. Yilmaz O., Ertuğrul, M., Some morphological traits of Donkeys Raised in Iğdir, Turkey. Iğdir Üniv. J. Inst. Sci. \& Tehn. 1 (2), 113-116, 2011.

6. Yilmaz O., Ertuğrul, M., The morphologic traits of Donkeys Raised in East and Southeast of Turkey. Hayvansal Üretim 53 (1), 10-13, 2012.

7. Kost'uková M., Jiskrová, I., Subotková, E., Petlachová, T., Píšová, M., Králová, B., Bihonková, I., Černohorská, H., Factors influencing the selected body parameters and hippometric indexes in donkey's population. Acta univ. agric. et silvic. Mendel. Brun. LX (6), 167-172, 2012.

8. StatSoft, Inc., STATISTICA (data analysis software system), version 6. www.statsoft.com, 2002. 